\title{
The Role of Government in Collective Bargaining: Scandinavia and the Low Countries
}

\author{
Ank Michels, University of Twente \\ Hans Slomp, University of Nijmegen
}

\begin{abstract}
This article compares the role of government in collective bargaining in five small West European countries. For the period until the second half of the 1970s, a distinction is made between countries in which government often interfered in wage bargaining, e.g. Denmark and The Netherlands, and countries in which government refrained from intervention, like Sweden. Belgium and, to a lesser degree. Norway. In all countries the tridtition of (non)intervention had already started before the Second World War. The article reviews some explanatory variables: in Scandinavia centralization of labour relations is crucial, in the Low Countries the nature of political verzuiling. Recent developments show that government intervention has become a characteristic of labour relations in all but one country.
\end{abstract}

\section{Introduction}

In the second half of the 1970s and in the 1980s national governments have intervened in labour relations in all small West European democracies. Only for some of these nations was this a new experience. Indeed, for the period between 1945 and 1975 one can make a clear distinction between countries in which government played an active role in labour relations and countries in which it did not. The distinction applies especially to wage bargaining, the core of employer-union relations. It does not say anything about the formation of social and economic policy: 'trilateralism' in the latter has been combined with both government abstinence and government intervention in wage bargaining.

The aim of this contribution is to demonstrate the difference between the two traditions, to offer some explanations and to trace back their origins. The distinction between the two traditions is all the more interesting since it cuts through Scandinavia. This could challenge the long-standing view of Scandinavia as a bloc of countries sharing the same social and political conditions.

Related to the rising star of neo-corporatism in the second half of the 1970s, the small nations of Western Europe have recently enjoyed wide 
attention in comparative literature on social and economic policy and on labour relations. From the very beginning the idea of wage restraint has dominated the discussion on neo-corporatism: union participation in the determination of social and economic policy was related to wage restraint as a union concession. The former could even represent a compensation for the latter. However, the role of government in wage bargaining has not been a major topic of discussion or research in neo-corporatism. In most of the literature on neo-corporatism the small nations (apart from Switzerland) have been treated as belonging to a similar tradition of corporatism.

This article contains a description of the role of government in collective bargaining for the period 1945-75 in the next section, and then offers some explanations. Following this the paper considers labour truces and legislation in the 1930s, and this is followed by a discussion of more general explanatory variables and some country-specific variables. Recent developments are then discussed, and a summary and conclusion complete the article. The survey covers Scandinavia and the Low Countries, i.e. Sweden, Norway, Denmark, The Netherlands and Belgium. In contrast to the other small nations, like Finland, Switzerland and Austria, their bargaining tradition dates back to the period before the Second World War. That allows us to study the pre-war roots of the tradition more in detail.

\section{Government Intervention in Wage Bargaining: 1945-75}

Table 1 demonstrates the frequency and the forms of government intervention. A distinction is made between government activity before the start of bargaining and government intervention in the bargaining process or in a conflict. In the former case the government takes the initiative; in the latter, wage bargaining is initially left to the employers' and workers' organizations.

The first category is divided into three sub-categories. Compulsory guidelines (cat. 1a) are the strongest form of government activity. Wage policy other than strict wage guidelines (e.g. tax measures or a maximum to price compensation, cat. 1b) leaves more room for bargaining. Tripartism (cat. 1c) is the weakest form of pre-bargaining intervention: the government negotiates with the labour-market organizations, but does not set limits to wage increases.

The second category, intervention in the process of bargaining or in a conflict, is also divided into three sub-categories. A direct government measure (cat. 2a) is a severe form of government intervention, even more than $1 \mathrm{~b}$ and $1 \mathrm{c}$. It limits wage rise, without necessarily enjoying the support 
Table 1. Forms of Government Intervention.

\begin{tabular}{|c|c|c|c|c|c|}
\hline & Sweden & Norway & Denmark & Netherlands & Belgium \\
\hline 1946 & & $1 b+2 b$ & $2 a$ & 1 & $1 \mathrm{a}$ \\
\hline 1947 & & $1 \mathrm{a}$ & $2 a$ & 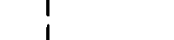 & la \\
\hline 1948 & & & & 1 & la \\
\hline 1949 & & $1 b+2 b$ & & 1 & \\
\hline 1950 & & 1 & & 1 & \\
\hline 1951 & & 1 & & T & $2 c$ \\
\hline 1952 & & 1 & & 1 & \\
\hline 1953 & & & & I 1a & \\
\hline 1954 & & & & 1 & \\
\hline 1955 & & & & i & $2 c$ \\
\hline 1956 & & & $2 a$ & i & \\
\hline 1957 & & & & i & \\
\hline 1958 & & $2 b$ & & $i$ & \\
\hline 1959 & & & & 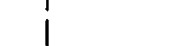 & \\
\hline 1960 & & & & 1 & \\
\hline 1961 & & & $2 a$ & $i$ & \\
\hline 1962 & & & & $j$ & \\
\hline $\begin{array}{l}1963 \\
1964\end{array}$ & & & $i^{1 a}$ & 1 & \\
\hline $\begin{array}{l}1964 \\
1965\end{array}$ & & $2 b$ & $i$ & (1a) & \\
\hline 1966 & & $2 b$ & $i$ & (1) & \\
\hline 1967 & & & 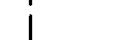 & 1 & \\
\hline 1968 & & & $1 b$ & & \\
\hline 1969 & & & 1 & $2 a$ & \\
\hline 1970 & & & 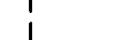 & & \\
\hline 1971 & $2 a$ & & 1 & la & \\
\hline 1972 & & & 1 & & \\
\hline 1973 & & & 1 & & \\
\hline 1974 & 1 & & 1 & 1a & \\
\hline 1975 & 1 & & $1 b+2 a$ & & \\
\hline 1976 & 1 & 1 & la & $1 \mathrm{a}$ & $1 b$ \\
\hline 1977 & i & i 16 & $1 b+2 a$ & & lb \\
\hline 1978 & $i$ & 1 & lb & & \\
\hline 1979 & 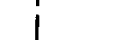 & la & $1 b+2 a$ & & \\
\hline 1980 & 1 & 1 & $1 b$ & 1a & $1 c$ \\
\hline 1981 & $1 \mathrm{c}$ & 1 & lb & $1 b$ & $1 \mathrm{a}$ \\
\hline 1982 & 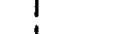 & I 16 & $1 a$ & 16 & la \\
\hline 1983 & 1 & & & & la \\
\hline 1984 & I & $1 b+2 b$ & 1 & & \\
\hline 1985 & I & 1 & 1 & & \\
\hline 1986 & 1 & & 16 & & \\
\hline 1987 & i & $1 b$ & 1 & & \\
\hline 1988 & $i$ & $1 b+2 a$ & 1 & & \\
\hline
\end{tabular}

1 Government activity before the start of bargaining:

a Compulsory guidelines

b Wage policy other than strict guidelines

c Tripartism

2 Government intervention in bargaining or conflict

a Direct government measure

b Compulsory arbitration

c Voluntary mediation

(1a) Compulsory guidelines, less strictly followed than in the period before.

Source: country-specific literature listed in the text. 
of trade unions and employers. Compulsory arbitration (cat. 2b) forces the parties to comply with government arbitration. Normally, however, arbitration is preceded by intensive consultation and is backed by both parties. Voluntary mediation (cat. $2 \mathrm{c}$ ) is the weakest form of government intervention, since it does not affect the bargaining process at all. In Scandinavia this latter form of government interference is widespread, and part of an extensive pattern of conflict control. Being common practice, it is not mentioned in the table. The table lists only years in which government intervention affected a large part of the economy.

\section{Sweden}

In the 1950s and the first half of the 1960s, bargaining in Sweden was concentrated at sectoral level. Since 1956 general agreements have provided a global framework for such sectoral negotiations. The Swedish government did not interfere until 1971, when groups of central and local government employees went on strike. A law was passed to prolong all collective agreements and to ban industrial actions for a period of six weeks. The intervention was a very specific case, however, since it concerned state employees (Elvander 1980, 157-158; Forsebäck 1980).

\section{Norway}

The Norwegian organizations tried to co-ordinate sectoral-level bargaining in central negotiations from 1963 onwards, but they were not very successful. Sectoral agreements continued to dominate Norwegian industrial relations.

In the first years following the Second World War, Norwegian governments pursued a vigorous policy of price and wage control. Compulsory arbitration, dating from before the war, was reintroduced. In 1952 the system was changed into one of voluntary arbitration by the tripartite National Wage Board and local wage committees. In the face of the threat of a large conflict, government might still try compulsory arbitration, after consultation between the parties. In fact, compulsory arbitration was employed almost every year, but on only three occasions was it imposed on the private sector as a whole - in 1958, 1964 and 1966. It should be stressed that Norway is the only country with such a great variety of arbitration measures (Norwegian Joint Committee on International Social Policy 1975; Esping-Andersen 1985, 218-219).

\section{Denmark}

As in Sweden and Norway there was a (gradual) transition to more cen- 
tralized bargaining. However, bargaining has always been less centralized than in the other Scandinavian countries.

In Denmark, government intervention has been a distinctive feature of wage bargaining since 1945 . If the parties failed to reach an agreement and also rejected the mediation proposal of the State Mediator, government intervened by means of enacting the mediation proposal into law. Intervention affected most of the private sector in 1946,1947, 1956 and, notably, 1961. Until 1956 government intervention usually favoured the unions. In 1956, for the first time a mediation proposal was made law which had been rejected by the trade-union federation. As in 1956, intervention in 1961 followed upon a period of major strikes. In the 1960s government interference in labour relations was reinforced. Already in 1963, before the start of negotiations, the government imposed a package of measures fixing wages and prices. This Helhedsløsning remained the only instance of compulsory wage guidelines in the period 1945-75, however. Since 1963 government has presented a macro-economic framework for negotiations almost every year. Moreover, it has regularly defined limits to wage increases, e.g. by fixing a maximum to the price compensation (Ibsen \& Jørgensen 1979, 114-140, 301-324; Michels 1986, ch. 5).

\section{The Netherlands}

Although sectoral agreements constituted the core of the Dutch bargaining system, until 1968 they were subject to a strict 'Guided Wage Policy'. In the formation and implementation of this policy the (three) trade-union federations and (two) employers' associations co-operated with government in a very intimate and formalized way.

From 1945 to 1959 a 'Board of State Mediators' checked if collective agreements were in accordance with the strict guidelines on wage increase, which were issued by the government after consultation each year with the peak organizations. In 1959 the Board was abolished and the peak organizations themselves took over its task. From then on they not only advised government on the wage guidelines, but also implemented wage policy. In 1963-64 the tight labour market caused an erosion of wage policy and in 1968 it was given up. In 1970 a law established free bargaining, but at the same time established the government's right to interfere in the event of wages endangering the national interest. Already in the same year the government applied the law for the first time and issued a wage pause (Windmuller et al. 1983, chs 5-7, 12).

Belgium

Belgian wage bargaining has comprised a combination of sectoral agree- 
ments and enterprise bargaining in the larger (i.e. mostly Walloon) enterprises. In the 1950s wage negotiations were hardly co-ordinated by the peak organizations. In the 1960 s central co-ordination, or 'social programmation' as it was called, was introduced, but it hardly affected wage bargaining.

Apart from a few years after liberation, when collective bargaining was subject to state measures, government has never interfered in bargaining. Exceptionally (e.g. in 1952 and 1955) it was involved as a one-time mediator, upon request of the labour-market parties (Slomp \& van Mierlo 1984, vol. 2, chs 7, 9).

\section{Some Explanations}

As the survey shows, the five nations differed in frequency and scope of government intervention. In Sweden intervention was totally absent, in Belgium it was absent after the years of reconstruction. In Norway state intervention was reduced in 1952 to arbitration in case of protracted disagreement in sectoral bargaining. In neither of these countries did government determine the level of wages, as it did in The Netherlands and regularly also in Denmark. In The Netherlands strict guidelines were the rule, and in Denmark intervention was also rather common.

For possible explanations of this difference between Sweden, Norway and Belgium on the one hand and The Netherlands and Denmark on the other, one might look both to government and to the nature of labour relations. In particular, participation of social democrats in government, centralization of labour relations and stability in the rate of labour conflicts probably favour non-intervention.

Social-democrat participation in government (see Table 2) has this effect because of the rather strict separation between political action and industrial action in the labour relations of northern continental Europe. The separation has been one of the early characteristics of social-democratic labour movements. It has been conducive to the division of labour in a political party for political action and trade unions for industrial action. The division of labour is apparent also in the relative absence of political strikes in this part of Europe (Bean 1986, chs 2, 5; Slomp 1990, chs 3, 4). Employers oppose state intervention in the case of social-democratic participation in government, since they fear intervention might favour the unions.

Centralization of bargaining may actually be a device to prevent government intervention. It certainly makes intervention a more tricky affair since it is bound to offend one of the peak organizations. In the case of decentralized bargaining the effect is different, since the central organ- 
Table 2. Years of Social-democratic Participation in Government 1930-88.

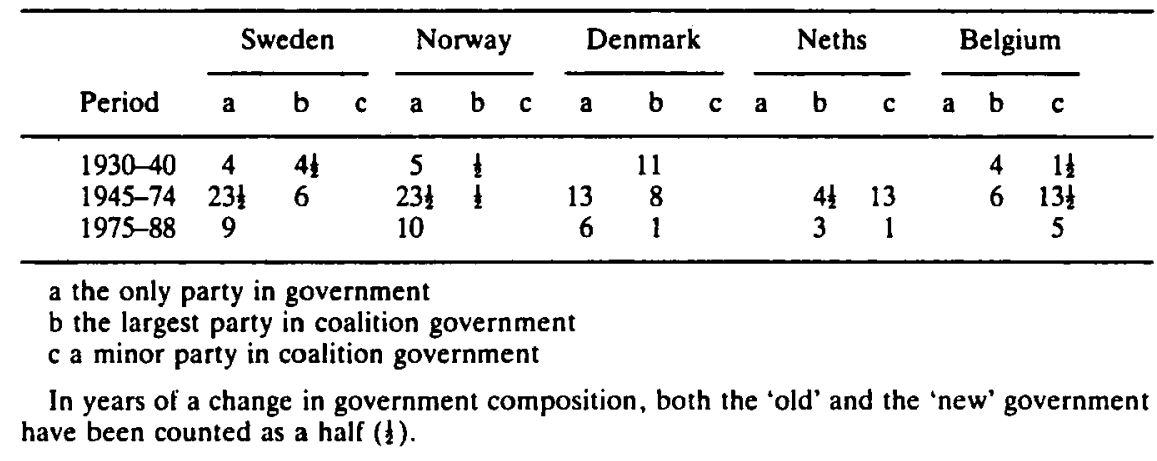

izations can stay aloof. The third factor, stability of the rate of conflict, reduces the need of any state intervention.

In Scandinavia there is a clear relation between social-democratic participation and government abstinence in labour relations. In Sweden and Norway social democrats participated or, even better, were the only party in government for most of the time. In Denmark they participated less often and were involved more frequently in coalition governments (Elvander 1980, 18). The relation does not hold in the Low Countries. In both countries social democrats participated less often and as a minor party most of the time, but the two countries differ completely in degree of government intervention (Geul et al. 1986).

The second explanation, centralization of bargaining, also holds true for Scandinavia. The labour movement and the employers' organizations in Norway and Sweden have been far more centralized than in Denmark (Esping-Andersen 1985, 58-63). In the latter country the continued existence of a number of craft unions prevented more centralization. Notably in Sweden, early centralization, related to the unions' 'solidaristic wage policy', allowed central bargaining and prevented government intervention. Again, this explanation applies to Scandinavia alone. In Belgium both the labour-movement and employers' organizations were far less centralized than in any Scandinavian country. During the 1950s central-level contacts were rare; during the 1960 s they took place, but without much effect on sector-level bargaining (Slomp \& van Mierlo 1984, chs 8, 10). Nevertheless, government did not interfere in bargaining. The Netherlands is a rather specific case, since centralization and wage policy were intimately related. Although bargaining took place in each industry separately, the central organizations used the function of consultation with government to keep their member organizations under control (Windmuller et al. 1983, chs 4, 
5). Thus, Belgium and The Netherlands run against the argument of a relation between centralization and non-intervention.

The third explanatory variable is variation in labour conflicts. In Sweden and Norway the rate of conflict has been low since the Second World War, with only minor variation between the years (Elvander 1980, 154-155). Denmark has an even lower strike profile, but it has been interrupted by exceptional years in which the number of working days lost surpasses even the 'top years' of Sweden and Norway taken together (ibid. 153). In these years, 1946, 1956, 1961 and 1973, government interfered, but the incidence is probably too low to speak of a relation between instability of strike rate and government intervention. Anyway, the relation is specific for Scandinavia, again. The Netherlands not only has a very low strike level, but also a very stable one (Windmuller et al. 1983, 217, 392). Belgium has the highest strike rate of the five nations, but without much variation either, apart from political strikes, e.g. in 1950 and 1960 (Slomp \& van Mierlo 1984, vol. 2, 244-245). This means that the variation of the strike rate does not explain intervention in The Netherlands and non-intervention in Belgium.

Thus, the three explanatory variables apply to Scandinavia. The first two explanations in particular, government composition and centralization of bargaining, could offer a clue to the difference in government involvement between Norway and Sweden on the one hand, and Denmark on the other. They do not apply to the Low Countries, however. Are Scandinavia and the Low Countries, then, as combinations of national cases, too different to be compared? A crucial difference could be the minor position of social democrats vis-à-vis Christian democrats in government most of the time if social democrats participated at all. A second differenre is the existence of the Christian-democrat union movement. In Belgium it even surpassed the socialist movement in numbers in the late 1950s.

Apart from these explanatory variables, a second course to an explanation could be to go back into history. Did a tradition of (non-)intervention already exist before the war? Since government intervention in Denmark started in the 1930s and Dutch legislation on intervention was passed in the same period, we turn to that decade of crisis.

\section{Labour Truces and Labour Legislation in the 1930s}

The crisis of the 1930s and the changes in international politics were the main background for a number of labour truces and for labour legislation. Both labour truces and legislation were attempts to promote sectoral wage bargaining and to keep down the number of conflicts, as a condition for economic recovery. Agreements were concluded in Sweden (1938), Norway 
(1935) and Belgium (1936). Legislation on collective bargaining was passed in Denmark (1933) and The Netherlands (1937).

\section{Sweden}

In the first half of the 1930s Sweden had a high strike rate. After 1935-36 economic conditions improved and the strike rate declined, under a coalition of social democrats and the farmers' party. Although this government, like its (social-democratic) predecessors, refrained from intervention in labour conflicts, there was some fear of such intervention, especially among employers. This fear was one of the backgrounds to the Saltsjöbaden agreement of 1938. The agreement provided for a permanent Labour Market Council as a central forum of the two labour-market parties (Elvander 1980, 72-73; Forsebäck 1980, 10-12).

\section{Norway}

The Norwegian agreement of 1935, Hovedavtale, banned strikes during the term of a collective agreement and introduced procedures for starting and mediating conflicts. It recognized the right to organize, and laid down rights and obligations of the Norwegian shop stewards. The agreement was preceded by years of a high strike rate, including the largest conflict in Norwegian industrial history, in 1931, which had lasted for five months. After a peak of over 30 percent, unemployment was falling again at the time of the truce. Political conditions changed as well. The social democrats had raised their votes in the elections of 1933 from 31.4 to an unprecedented 40.1 percent, and in 1935 they succeeded a liberal government. The truce was concluded eleven days before this cabinet was installed. The social democrat rise to power was an explicit precondition of the truce. The tradeunion federation wanted to prevent labour conflicts, and the employers to keep government out of bargaining (Galenson 1949, 192-196; Elvander $1980,72)$.

\section{Denmark}

In 1933, Denmark proclaimed a one-year freeze of labour conditions (prolonging all existing agreements by one year) and a ban on strikes and lock-outs during that period. The measure was part of a broad package of government measures, called the Kanslergadeforlig, aimed to support the farmers and the unemployed.

The measure was taken by a coalition cabinet of social democrats and left-wing liberals (Radikale Venstre), in power since 1929. It was preceded by the employers' demand to cut wages by 20 percent. Since the wage stop 
prevented any such wage cut, the trade-union movement expressed only a weak protest. Economic considerations were probably an overriding concern in this rather specific measure, the more so since unemployment had reached a peak of over 30 percent. The intervention of 1933 was followed by similar though less strong government action in 1937, 1938 and 1939 (Galenson 1952, 130-132; Ibsen \& Jørgensen 1979, 18-23).

\section{The Netherlands}

The Dutch conservative-confessional governments did not leave the gold standard until 1936 and as a consequence the growth of unemployment continued until that year. One of the few anti-crisis measures before that time was a law in 1935 to promote cartelization. It provided government with the right to declare cartel agreements binding upon protesting industrialists.

The cartel law was the last cause for a law in 1937 providing the same facilities for sectoral collective agreements. Like the cartel law, the new law allowed government to undo any collective agreement. The argument for this unique provision, which allowed the curbing of wages, was one of principle, rather than fear of a wage drift following the devaluation. Labour conflicts did not pose a problem, since the rate of conflict had been very low since the beginning of the crisis. Thus, government intervention in wage formation was legalized rather early in The Netherlands. Social democrats played no role in this legislation; they did not participate in government until 1939 (Windmuller et al. 1983, 71-75).

\section{Belgium}

In 1936, when unemployment was definitely on the decline, both socialists and Christian democrats lost 21 seats to the fascist REX movement. After the socialist failure to form a cabinet, a strike broke out in Antwerp. It spread throughout the country, and became the largest labour conflict in pre-war Belgian history. The socialist and Catholic unions at first attributed the actions to fascist rioters, but the disappointment about the socialdemocratic performance in the elections also played a role. After a while the socialist union movement, later joined by the Catholic union organization, reluctantly supported the strikes and then demanded the new (Catholic) prime minister to force the employers' organization to the bargaining table. It probably wanted to get some compensation for what it might have got under a social-democratic prime minister.

In a scenario similar to that of Matignon in France three months before, the Prime Minister presided over a 'Labour Conference'. The conference was followed by a revival of bargaining in existing or newly created 'parity 
committees'. In December 1939, after the outbreak of the Second World War, a second Labour Conference was held, to stabilize wages (Slomp \& van Mierlo 1984, vol. 1, 176-182).

\section{General and Country-specific Explanations}

To some extent the distinction between Sweden, Norway and Belgium on the one hand and Denmark and The Netherlands on the other dates from the 1930s. Although in Sweden and Norway government intervention was in the background, a central agreement prevented such intervention. The aim of government intervention in Belgium in 1936 was not to decide on labour conditions, but to encourage, if not enforce, negotiations. The pattern of post-war intervention in Denmark was set by regular interference. In The Netherlands, government did not interfere directly but laid down the principle of intervention in a law.

It is tempting to look at the same explanatory variables as those of the post-war period in order to find an explanation for the differences of the 1930s: if they do not offer a complete explanation for the post-war continuation of traditions of (non-)intervention, do they apply to the beginning of the tradition?

In particular, government composition could be of importance, since it was involved as an issue in Norway and possibly also in Belgium. Government composition (in particular, social-democratic participation) does not offer an explanation, however, not even for Scandinavia. In Denmark social democrats were the largest party in government during the whole decade, while in Sweden they were the largest party or they governed without a coalition partner from 1932 onwards. In Norway they monopolized government after 1935; in Belgium they participated from 1935 onwards; and in The Netherlands they were kept out of government by the large Catholic party. Thus, both intervention and non-intervention occurred under governments with and without a social-democratic element.

Differences in the degree of centralization were already the same as those after the war: relative centralization in Norway and Sweden, relative decentralization in The Netherlands, Denmark and Belgium. The Belgian Labour Conference of 1936 could suggest a high degree of centralization, but the socialist union confederation did not even have a common strike fund by that time. (It set up such a fund in 1937, in reaction to the events of 1936.)

The trends in the rate of strikes were very diverse in the 1930s and in general there was more variation between the countries and over time than after the war. In view of the short period involved since the outbreak of the crisis the rate of conflict might be more important than the time 
variations in strike rate. In Sweden the rate was very high until 1934. In 1938 there was a new peak. In contrast, the Norwegian agreement was concluded at a low tide of conflict. The strike rate under the agreement (1936-39) was even higher than in the first half of the 1930s! Denmark had a low level of conflict after 1932, and The Netherlands after 1933. In Denmark this low level was interrupted by an occasional very high strike rate in 1936. In Belgium the Labour Conference was related to an outburst of strike activity. Thus, both intervention and non-intervention were related to a low strike rate and stability in the rate of conflict (Galenson 1952, 285290; Windmuller et al. 1983, 217; Slomp \& van Mierlo 1984, vol. 2, 244 245).

This means there is no overall explanation for the differences in intervention in the 1930s. Degree of centralization may offer an explanation for Scandinavia; cabinet composition does not.

Although the search for explanations has been a seemingly disappointing one, at least there is clarity on one point: the variation in degree of government intervention has its roots in the 1930s. Concerning the explanatory variables, only centralization can count as one, and it applies to Scandinavia alone.

To explain the differences in intervention between The Netherlands and Belgium, we should probably turn to a political phenomenon: verzuiling (i.e. the existence of rather isolated 'blocs' of socialist and Catholic organizations, including political parties, trade unions and employers' organizations).

Though verzuiling has been a predominant characteristic of politics in both countries, the effects on the place of national government have been quite opposed. Until recently the Dutch verzuiling consisted of three blocs (Catholic, Protestant, social democratic). Since all governments were coalitions of at least two blocs (Catholic and Protestant), they could develop a position of uncontested neutrality, 'above the parties'. Governments reinforced their position by a heavy emphasis on economic conditions, as 'objective' parameters of wage increase, and wage policy: almost without exception, Dutch labour relations and government intervention reflected changes in economic conditions (Slomp 1985; Geul et al. 1986). In contrast, the Belgian pattern of verzuiling implied a division in two blocs (Catholic, social democratic), hence a polarization of social and political life. This did not leave much room for 'objective' parameters like those applied in The Netherlands. Moreover, government intervention (whether by Catholics or social democrats) would seriously strain the relations between the socialist organizations and their traditionally uproarious members in Wallony and could easily lead to widespread labour revolt. While avoiding political conflict in The Netherlands rests on 'depoliticization', in the form 
of government intervention applying 'objective', i.e. economic, yardsticks, in Belgium it is possible only by government abstinence.

This explanation of variation between The Netherlands and Belgium reinforces the idea that both the sphere of labour relations and the sphere of politics may offer explanations: centralization of labour relations in Scandinavia and the nature of politics in the Low Countries.

\section{Recent Developments}

From the mid-1970s onwards, the small countries have been affected by an economic recession. In response to this change in economic conditions, the governments in all five countries have been involved in collective bargaining for the last 15 years. This could imply either a break with the past or a continuation of existing practice. The degree of government intervention in collective bargaining and the form it took has not been the same, however (see Table 1).

State interference in collective bargaining has been least far-reaching in Sweden: the government did not impose a wage policy or intervene directly. However, in the 1970s and 1980s government often negotiated with the labour-market organizations and on some occasions offered compensation for wage restraint.

In Norway there has also been a shift towards more government intervention. In 1976, for the first time, tripartite negotiations were held. From that time government has regularly participated in central-level negotiations, in order to fix maximum wage increases and to construct a (new) framework for union-employer negotiations. In 1979 and 1988 government laid down severe restrictions to wages - in 1979 by means of compulsory guidelines, and in 1988 by enacting the agreement between the central organizations in order to stave off wage drift.

Government involvement in Belgium started in 1975. At first government intervened indirectly by means of a tax on wage increases. In the early 1980s government intervention was more direct. If the central organizations failed to reach an agreement, a law was passed to stabilize wages. The law could be replaced by an agreement, on condition that the latter provided for the same wage restraint as the law. In 1986, for the first time since the 1970 s, a 'real' agreement was concluded between the labour-market organizations again.

In Denmark, intervention in collective bargaining has continued in two ways: firstly, by a rigid incomes policy, fixing maximum wage increases, and secondly, by mediation proposals and wage stops if negotiations fail. The latter condition was met several times in the 1970s. In the 1980 s most agreements between employers and unions have been concluded without government intervention. 
Dutch governments have continued the tradition of heavy state involvement in wage determination. Although formal wage policy had been given up in 1968, the government intervened several times in the 1970 s by means of wage freezes and wage pauses. Since 1982 government intervention has decreased. This is partly due to the disappearance of the very intricate system of linkages between wages in the public sector, wages in the private sector and social-security benefits. The public sector and social security have lagged behind wage developments in the private sector. This has caused the trade-union movement to moderate wage demands in the private sector.

Thus, in all countries government has become involved in wage bargaining and one can no longer make a clear-cut distinction between two groups of countries with respect to government intervention. However, the degree of intervention is different for the five countries. In Sweden it represents a gradual change, rather than a break with a long tradition of non-intervention. Government intervention in Sweden is less far-reaching than in the other nations. In Belgium, and to a lesser degree Norway, there has been a clear increase in government intervention, representing a break with the past. In Denmark and The Netherlands government intervention has remained an aspect of labour relations. Government retreat in the 1980 s can only be explained by the lasting structural crisis in these countries, which forces the trade-union movement on the defensive and thus has a moderating influence on wage demands. When the economy recovers, wage claims may well, or even may probably, lead to renewed government intervention.

\section{Summary and Conclusion}

Literature of neo-corporatism concentrates on the co-operation between government, employers' associations and the trade-union federations in the formulation and implementation of social and socioeconomic policy. Wage restraint is an important condition of the success of neo-corporatism. However, the role of government in collective bargaining and wage determination has hardly been a topic of discussion and research in neo-corporatist theories.

In this article we described the role of government in collective bargaining for five small West European countries. It appears that, for the period until the second half of the 1970s, a distinction can be made between countries in which government interfered often in wage bargaining, e.g. Denmark and The Netherlands, and countries in which government refrained from intervention, like Sweden, Belgium and, to a lesser degree, Norway. In this respect Denmark shows more similarities with The Netherlands than with Norway and Sweden. 
In Scandinavia, centralization of labour relations is crucial, in the Low Countries the nature of political verzuiling. In all countries the tradition of (non-)intervention had already started before the war. Recent developments show that government intervention has become a characteristic of labour relations in all but one country, even in countries which had a long tradition of non-intervention.

\section{REFERENCES}

Bean, R. 1986. Comparative Industrial Relations. Beckenham: Croom Helm.

Elvander, N. 1980. Skandinavisk arbetarrörelse. Stockholm: LiberFörlag.

Esping-Andersen, G. 1985. Politics against Markets. Princeton. NJ: Princeton University Press.

Forsebäck, L. 1980. Industrial Relations and Employment in Sweden. Stockholm: Swedish Institute.

Galenson. W. 1949. Labor in Norway. Cambridge, Mass.: Harvard University Press.

Galenson, W. 1952. The Danish System of Labor Relations. Cambridge. Mass.: Harvard University Press.

Geul, A.. Nobelen, P. \& Slomp, H. 1986. 'The Future of Tripartism in the Low Countries', in: ten Hove, M. D., ed., The Institutions of a Changing Welfare State. Maastricht: Presses Interuniversitaires Européenes, 27-34.

Geul, A., Slomp. H. \& van Snippenburg. L. B. 1986. 'Vakbondskkracht en vakbondsinvloed in Nederland en België', Tijdschrifı voor Arbeidsvraagstukken 2, 5-1.3.

Ibsen, F. \& Jørgensen, H. 1979. Fagbevagelse og stat II, den faglige kamp, statsindgreb og indkomstpolitik 1930-78. Copenhagen: Gyldendal.

Katzenstein. P. J. 1985. Small States in World Markets. Ithacal and London: Cornell University Press.

Michels, A. 1986. Labour Relations in Denmurk. Copenhagen/Nijmegen (unpublished).

Norwegian Joint Committee on International Social Policy. 1975. Labour Relations in Norway. Oslo.

Peterson, R. B. 1987. 'Swedish Collective Bargaining, a Changing Scene'. British Joturnal of Industrial Relations 2, 31-48.

Slomp, H. 1985. 'Politiek en centraal overleg', Tijdschrift voor Arbeidsvraagstukken 1, 3034.

Slomp, H. 1990. Labor Relations in Europe. Westport. CT: Greenwood Press.

Slomp, H. \& van Mierlo, T. 1984. Arbeidsverhoudingen in België, 2 vois. Utrecht: Het Spectrum.

Windmuller, J. P., de Galan. C. \& van Zweeden, A. F. 1983. Arbeidsverhoudingen in Nederland. Utrecht: Het Spectrum. 